\title{
Efficiency of some plants powder mix as a dietary supplement for silkworm (Bombyx mori L.)
}

\author{
Hassan S.I ${ }^{1 *}$, S.H. Rateb ${ }^{2}$, K.M. Mohanny ${ }^{1}$ and M.H. Hussein ${ }^{2}$
}

${ }^{1}$ Plant Protection Department, Faculty of Agriculture, South Valley University, Qena, Egypt

${ }^{2}$ Plant Protection Department, Faculty of Agriculture, Assuit University, Assuit, Egypt

\begin{abstract}
Bombyx mori L. is one of the most economically important insects because of its production of silk. In this study, we investigated the effect of four plants powder mix on larvae weight, silk gland weight, cocoon parameters and fecundity of moths in two hybrids (local and imported) of silkworm. The most desirable effects (increased final larvae weight by over $8.93 \%$, silk gland weight by over $37.45 \%$, cocoon shell weight by over $39.84 \%$ and No. of eggs by over $28.93 \%$ ) was obtained by treatment of mulberry leaves with (M2) in local hybrid. Meanwhile in imported hybrid the most desirable effects (increased final larvae weight by over $3.75 \%$, silk gland weight by over $51.29 \%$. cocoon shell weight by over $22.17 \%$ and No. of eggs by over $55.87 \%$ ) was got by treatment of mulberry leaves with (M3) and feed it to the larvae. According to the results, It can enrich the nutrient quality of mulberry leaves provided to the silkworm by adding such plant materials, which lead to raising the efficiency of larvae productivity, increasing the quantity and quality of cocoons, and then improving the production of silk.
\end{abstract}

Keywords: Silkworm; Plants powder mix; Cocoon parameters.

\section{Introduction}

Bombyx mori L is a highly sensitive lepidopteron insect because it was domesticated for thousands of years. Silkworm is being a monophagus insect and typical caterpillar so it feeds exclusively on mulberry leaf during its larval stages which account for nearly half of its total life span. The food that is consumed during larval stages utilized for growth as well as accumulation of energy reserves to fuel its metabolisms during nonfeeding periods like larval molting, spinning, pupal and adult stages of silkworm (Naik and

*Corresponding author: Safaa I. Hassan

Email: s.ismail@agr.svu.edu.eg

Received: September 04, 2020;

Accepted: November 22, 2020;

Published: September 8, 2020.
Naik, 2015). The nutritive quality plays an important role on the growth and development of worm, stabilizing the cocoon production and silk productivity. Production performance of silkworm play a pivotal role in sericulture industry and good quality cocoon is the main purpose of the silkworm rearing (Samami et al., 2019). In order to improve the quality of silk and quantity of cocoons it is necessary to enrich the nutrient quality of mulberry leaves, this can be achieved by the supplementation of mulberry leaves with extra nutrients. In recent years, mulberry leaves are being fortified with nutrient supplement such as, carbohydrates, dietary proteins, amino acids, bee hive products, vitamins, phytoecdysteroids and combination of plant extracts to control 
diseases and also to improve the economical traits of silkworm which can be used for yield enhancement in sericulture industry (Sengupta et al., 1972; Manimuthu and Isaiarasu,2010; Borgohain, 2015; Sathis and Sujatha, 2020). Many plants had confirmed its effects on various stage life and economic parameters of silkworm such as increase the larval body weight, silk gland weight, cocoon as well as shell weight and maturation of silkmoth (Sridevi et al. 2003; Pardeshi et al. 2014; Singh and Saxena, 2015; Ismail et al., 2016; Saad et al., 2019). In view of these observations, in the present study, an attempt has been made to screening of various plants may be useful in augmenting commercial silk production and find new efficient supplementary for the feeding of mulberry silkworm through the use of some fodder additives which allow the improvement of bioproductive parameters.

\section{Materials and Methods}

Tow silkworm hybrids (local and imported) were obtained from Sericulture Research Department-Plant Protection Research Institute-Agricultural Research Center. Mulberry leaves of Morus alba var. Kanva-2 were used during experimental work. The experimental works were carried out in Laboratory of silkworm rearing, Plant Protection Department, Faculty of Agriculture, South Valley University, Qena, Egypt. Rearing of silkworm larvae was carried out under laboratory conditions of approximately $\left(25 \pm 2^{\circ} \mathrm{C}\right.$ and $75 \pm 5 \% \quad$ R.H $)$ without any adjustment or changes in temperature or relative humidity according to the technique of (Krishnaswami (1978). Experimental rearing was carried out with 750 larvae of uniform size recruited from the stock that has been reared and acclimatized. These larvae were formed into triplicates and placed separately in the rearing trays. This rearing involved to basic observations on growth of larvae (final larvae weight and silk gland weight), cocoon characteristics (cocoon, pupae, shell weight and cocoon shell ratio \%) and mother moth (ovariolis weight and number of laid eggs) of silkworm in response to the dietary supplementation. The readings of the experiment were taken by using the electronic scale (in grams). Deviation (\%) from control was calculated as (Hassan et al., 2019). Chicken egg cartons plates were used as montages for cocoon spinning as described by (Zannoon and Omera, 1994).

\section{Mulberry leaves treatment with additive mixture powders}

The mixture powders were dusted on clean mulberry leaves using fine mesh at rate of 1:15 w/w (powder/leaf). Also, the treated mulberry leaves were administrated to the larvae only in the first feed every day during feeding period of $4^{\text {th }}$ and $5^{\text {th }}$ instar larvae.

\section{Powders formulae preparation}

The fresh leaves from eight plant species were collected in early spring and dried in oven at $45{ }^{\circ} \mathrm{C}$ hr. 72 hours. Also, three main materials (mixed pollen loads, soybean flour and fructose) were obtained for preparing the powder mixtures. The five mixtures contents were in equal quantities ( $2 \mathrm{gms}$ ) from each one as fine powder form.

\section{Statistical analysis:}

Obtained data were analyzed using the factorial design. F-test was estimated for each analysis. The means were compared according to Duncan's Multiple Range Test.

Four powder treatments, including powders of dried plant leaves or seeds were tested on imported and local hybrid of silkworm. They were: 


\begin{tabular}{ll}
\hline Treat. No., & \multicolumn{1}{c}{ Treatments } \\
\hline M1 & (Main mixture $)+($ Eucalyptus globules L. \& Lens culinaris excdenta $)$ \\
M2 & (Main mixture $)+($ Ocimum basilicum L. \& Vigna unguiculate ) \\
M3 & (Main mixture $)+($ Mentha longifolia L. \& Phaseolus vulgaris $)$ \\
M4 & (Main mixture $)+($ Thymus vulgaris L. \& Vicia faba $)$ \\
Control & Mulberry leaves only \\
\hline
\end{tabular}

Main mixture: (Pollen + Soya flour + Fructose $)$

\section{Results and Discussion}

Mulberry leaves are the sole food plant for the silkworm. Supplementation of mulberry leaves with extra nutrients will serve as an alternate source to get heavy cocoons and improve the silk production. Plant, as it effects on the physiology of digestion and various metabolic activities resulting in improvement of growth and development of silkworm larva as well as cocoon formation and maturation of silkmoth. In the present study, the mean larval weight of the final instar larvae was increased significantly when compare to the control in both hybrids. Maximum increase in local hybrid was showed in M2 treatment, while in imported hybrid was in M4. The silk gland weight were found increased over the control (from $37.45 \%$ to $45.69 \%$ ) in local hybrid, while in imported hybrid were (from $16.05 \%$ to 37.74 ), this is due to the plants powder mix may be attributed some of biochemical process of protein synthesis. The quantity and quality of dietary protein has long been important in growth of the silkworm (Karthikairaj et al. 2013). All cocoons characters have been increased in both hybrids as a result of treating with treatments. (Murugan et al. 1998 \& Kumar and Gangwar 2010) have proved through some comparative studies that, the food plant of different species can influence the larval growth, larval duration, cocoon characters and fecundity of moths. In ovariolis weight the maximum weight was found in (M1) in local hybrid, while in imported hybrid the ovariolis weight got reduced due to the dietary supplementation of mix powders. An increase in the number of eggs has also been noticed in all treatment except in (M4) in both hybrids of silkworm. (El-Shewy and Elgizawy 2017) has disclosed the positive impacts on all the tested biological and physiological parameters upon feeding silkworm on alternative food during autumn season. Also, produced healthy cocoons and increased of eggs production. The overall performance of silkworm with response to influence of plants powder mix treatments observed in the present study and the evaluation index values worked out showed that the parameters observed were increased in the set that received of treatments. Therefore, the improvement of the growth and cocoon characteristics of the silkworm $B$. mori when larvae were supplemented with this plants powder mix may be attributed to the medicinal properties of plant and increased the dietary protein in nutrition feed which allow the improvement of bioproductive parameters. This study was only to find out the possibilities of growthand rearing performance of silkworm, with the supplementation of plants powder mix. 
Table 1: Effect of tested plants powder mix treatments on local hybrid of silkworm.

(Values are mean of observations; indicate percent of deviation from control and Duncan test)

\begin{tabular}{|c|c|c|c|c|c|c|c|c|c|c|c|c|c|c|c|c|}
\hline 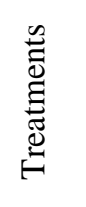 & 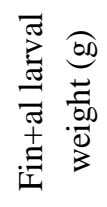 & * & 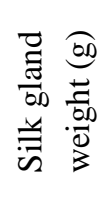 & $\stackrel{*}{*}$ & 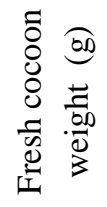 & * & 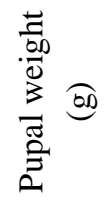 & * & 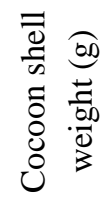 & $*$ & 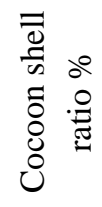 & $\tilde{Z}$ & 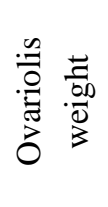 & $*$ & $\begin{array}{l}0 \\
00 \\
000 \\
0 \\
\dot{0} \\
Z\end{array}$ & * \\
\hline \multirow[t]{3}{*}{ M1 } & 3.119 & $\mathrm{~b}$ & 1.145 & $\mathrm{a}$ & 1.388 & $\mathrm{a}$ & 1.078 & $\mathrm{a}$ & 0.31 & $\mathrm{a}$ & 22.5 & $a b$ & 0.501 & $\mathrm{a}$ & 414 & $\mathrm{bc}$ \\
\hline & -16.6 & & +42.9 & & +12.3 & & +9.55 & & +23.5 & & $5 \%$ & & +13.6 & & 5.08 & \\
\hline & $5 \%$ & & $5 \%$ & & $9 \%$ & & $\%$ & & $1 \%$ & & & & $1 \%$ & & $\%$ & \\
\hline \multirow[t]{3}{*}{ M2 } & 4.076 & $\mathrm{a}$ & 1.101 & $\mathrm{a}$ & 1.453 & $\mathrm{~b}$ & 1.133 & $\mathrm{a}$ & 0.351 & $\mathrm{a}$ & 24.4 & $\mathrm{a}$ & 0.454 & $a b$ & 508 & $a b$ \\
\hline & +8.93 & & +37.4 & & +17.6 & & +15.1 & & +39.8 & & $7 \%$ & & +2.95 & & 28.93 & \\
\hline & $\%$ & & $5 \%$ & & $5 \%$ & & $4 \%$ & & $4 \%$ & & & & $\%$ & & $\%$ & \\
\hline \multirow[t]{3}{*}{ M3 } & 3.819 & $\mathrm{a}$ & 1.167 & $\mathrm{a}$ & 1.446 & $\mathrm{~b}$ & 1.125 & $\mathrm{a}$ & 0.322 & $\mathrm{a}$ & 22.5 & $a b$ & 0.44 & $a b$ & 562 & $\mathrm{a}$ \\
\hline & +2.06 & & +45.6 & & +17.0 & & +14.3 & & +28.2 & & $2 \%$ & & -0.23 & & 42.64 & \\
\hline & $\%$ & & $9 \%$ & & $9 \%$ & & $3 \%$ & & $9 \%$ & & & & $\%$ & & $\%$ & \\
\hline \multirow[t]{3}{*}{ M4 } & 3.856 & $\mathrm{a}$ & 1.079 & $\mathrm{a}$ & 1.473 & $\mathrm{~b}$ & 1.118 & $\mathrm{a}$ & 0.356 & $\mathrm{a}$ & 24.4 & $\mathrm{a}$ & 0.376 & $\mathrm{c}$ & 328 & $c$ \\
\hline & +3.05 & & +34.7 & & +19.2 & & +13.6 & & +41.8 & & $4 \%$ & & -14.74 & & -16.7 & \\
\hline & $\%$ & & $1 \%$ & & $7 \%$ & & $2 \%$ & & $3 \%$ & & & & $\%$ & & $5 \%$ & \\
\hline Cont & 3.742 & $\mathrm{a}$ & 0.801 & b & 1.235 & $\mathrm{c}$ & 0.984 & $\mathrm{~b}$ & 0.251 & $\mathrm{~b}$ & 20.5 & b & 0.441 & $a b$ & 394 & bc \\
\hline rol & $0 \%$ & & $0 \%$ & & $0 \%$ & & $0 \%$ & & $0 \%$ & & $6 \%$ & & $0 \%$ & & $0 \%$ & \\
\hline
\end{tabular}

Table 2: Effect of tested plants powder mix treatments on imported hybrid of silkworm..

(Values are mean of observations; indicate percent of deviation from control and Duncan test)

\begin{tabular}{|c|c|c|c|c|c|c|c|c|c|c|c|c|c|c|c|c|}
\hline 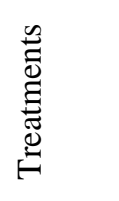 & 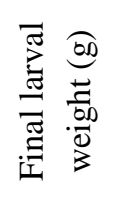 & $*$ & 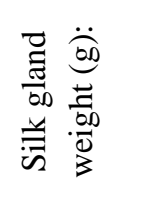 & * & 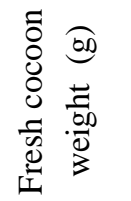 & $*$ & 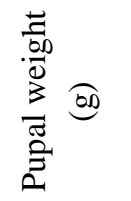 & $*$ & 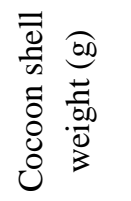 & $*$ & 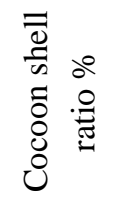 & $\begin{array}{l}\tilde{Z} \\
Z\end{array}$ & 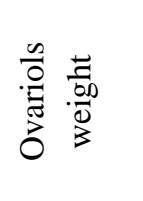 & 号 & $\begin{array}{l}\infty \\
00 \\
000 \\
0 \\
0 \\
\dot{Z}\end{array}$ & $*$ \\
\hline M1 & $\begin{array}{c}3.93 \\
-1.8 \%\end{array}$ & b & $\begin{array}{c}1.27 \\
+55.45 \%\end{array}$ & $\mathrm{a}$ & $\begin{array}{c}1.137 \\
5.47 \%\end{array}$ & $\mathrm{~b}$ & $\begin{array}{c}0.9 \\
3.93 \%\end{array}$ & $\mathrm{C}$ & $\begin{array}{c}0.236 \\
11.32 \%\end{array}$ & $\mathrm{c}$ & $\begin{array}{c}20.891 \\
+5.45 \%\end{array}$ & $\mathrm{a}$ & $\begin{array}{c}0.439 \\
-11.67 \%\end{array}$ & $\mathrm{a}$ & $\begin{array}{c}453 \\
83.4 \%\end{array}$ & A \\
\hline M2 & $\begin{array}{c}3.956 \\
-1.15 \%\end{array}$ & b & $\begin{array}{c}1.07 \\
+30.97 \%\end{array}$ & B & $\begin{array}{c}1.248 \\
15.77 \%\end{array}$ & $\mathrm{a}$ & $\begin{array}{c}0.985 \\
13.74 \%\end{array}$ & B & $\begin{array}{c}0.263 \\
24.06 \%\end{array}$ & $\mathrm{~b}$ & $\begin{array}{r}21.203 \\
+7.03 \%\end{array}$ & $\mathrm{a}$ & $\begin{array}{c}0.428 \\
-13.88 \%\end{array}$ & $\mathrm{a}$ & $\begin{array}{c}492 \\
99.19 \%\end{array}$ & A \\
\hline M3 & $\begin{array}{c}4.152 \\
+3.75 \%\end{array}$ & $\mathrm{ab}$ & $\begin{array}{c}1.236 \\
+51.29 \%\end{array}$ & $\mathrm{a}$ & $\begin{array}{c}1.25 \\
15.96 \%\end{array}$ & $\mathrm{a}$ & $\begin{array}{c}0.99 \\
14.32 \%\end{array}$ & $\mathrm{~B}$ & $\begin{array}{c}0.259 \\
22.17 \%\end{array}$ & $\mathrm{~b}$ & $\begin{array}{r}20.997 \\
+5.99 \%\end{array}$ & $\mathrm{a}$ & $\begin{array}{l}0.494 \\
-0.6 \%\end{array}$ & $\mathrm{a}$ & $\begin{array}{c}385 \\
55.87 \%\end{array}$ & $\mathrm{Ab}$ \\
\hline M4 & $\begin{array}{c}4.38 \\
+9.45 \%\end{array}$ & $\mathrm{a}$ & $\begin{array}{c}1.123 \\
+37.45 \%\end{array}$ & B & $\begin{array}{c}1.323 \\
22.73 \%\end{array}$ & $\mathrm{a}$ & $\begin{array}{c}1.048 \\
21.02 \%\end{array}$ & A & $\begin{array}{c}0.274 \\
29.25 \%\end{array}$ & $\mathrm{a}$ & $\begin{array}{c}21.14 \\
+6.71 \%\end{array}$ & $\mathrm{a}$ & $\begin{array}{c}0.483 \\
-2.82 \%\end{array}$ & $\mathrm{a}$ & $\begin{array}{c}164 \\
-33.6 \%\end{array}$ & $\mathrm{C}$ \\
\hline Control & $\begin{array}{c}4.002 \\
0 \%\end{array}$ & b & $\begin{array}{c}0.817 \\
0 \%\end{array}$ & $\mathrm{c}$ & $\begin{array}{c}1.078 \\
0 \%\end{array}$ & $\mathrm{~b}$ & $\begin{array}{c}0.866 \\
0 \%\end{array}$ & $\mathrm{C}$ & $\begin{array}{c}0.212 \\
0 \%\end{array}$ & $\mathrm{~d}$ & $\begin{array}{c}19.811 \\
0 \%\end{array}$ & $\mathrm{a}$ & $\begin{array}{c}0.497 \\
0 \%\end{array}$ & $\mathrm{a}$ & $\begin{array}{l}247 \\
0 \%\end{array}$ & $\mathrm{Bc}$ \\
\hline
\end{tabular}

Mean within the same column followed by the same letter do not differ significantly at 5\% level of probability 


\section{Conclusion:}

The average of the evolution index values clearly indicate that, these plants powder mix increase growth, cocoon parameters and fecundity of moths of silkworm in the experimental sets over the control. According to the results, these additives could improve the economical traits of silkworm which can be improve the productivity of silkworm and thus improve the silk industry.

\section{References}

Borgohain, A. (2015) 'Nutritional supplement and its effect on mulberry silkworm Bombyx mori L.' Int. J. Innovative Research in Science, Engineering, and Technology, 4(8): pp. 6961-6962.

El-Shewy, A.M. and Elgizawy, K. KH. (2017) 'Effect of alternative plants on physiological and biological characteristics of silkworm Bombyx mori L.' Middle East J. Agric. Res., 6(4): 1268-1272.

Hassan, S.I., S.H. Rateb, K. Mohanna and M.H. Hussein (2019) ' Effect of some plant extracts and powders on the growth and productivity of mulberry silkworm' Thesis, Fac. Of Agric. Sci., Assiut, Egypt,138.

Ismail. S., S.H. Rateb, K. Mohanna and M.H. Hussein (2016) 'Using of some plant extracts and honeybee products for feeding of imported and local hybrids of mulberry silkworm (Bombyx mori L.)' J. Plant Prot. and Path., Mansoura Univ., 7(2): $137-142$.

Karthikairaj, K., P. Sureshkumar and L. Isaiarasu (2013) 'Influence of Turmeric Extract on the Growth and Commercial Parameters of Bombyx mori L. (Lepidoptera: Bombicidae)' African J. Basic \& Appl. Sci., 5 (5): 228-231.
Krishnaswami, S. (1978) New technology of silkworm rearing Central Sericulture Research and Training Institute, Mysore, $1-23$.

Murugan, K., D. Jeyabalan, N. Senthilkumar, S. Senthilanathan and N. Sivaprakasam (1998) 'Growth promoting effect of plant products on silkworm' $A$ Biotechnological Approach. J. Sci. and Ind. Res., 57: 740-745.

Kumar, R. and Gangwar, S. K. (2010) Impact of varietal feeding on Samia ricini Donovan in spring and autumn season of Uttar Pradesh'. ARPN Journal of Agricultural and Biological Science, 5(3), 46-51.

Manimuthu, M. and L. Isaiarasu (2010)' Influence of herbal tonic aloe on the overall performance of the mulberry silkworm, Bombyx mori L.' J. Biopesticide, 3 (3): 567-572

Naik, M. J. and Naik, A. S. (2015) 'Impact of botanical extracts on histopathology of silkworm (Bombyx mori L.)'. Journal of Experimental Biology and Agricultural Sciences, 3(3), 281-287.

Pardeshi, A.B. and P.N. Bajad (2014) 'The effect of nutritional supplementation with Amaranthus hybrids Linn. extract on the economic performance of mulberry silkworm, Bombyx mori L.' Sch. Acad. J. Biosci., 2 (4): 272-276.

Saad, M. S., Elyamani, E. M.and Helaly, W. M. (2019) 'Controlling of bacterial and fungal diseases that contaminating mulberry silkworm, Bombyx mori by using some plant extracts'. Bulletin of the National Research Centre, 43(1), 172.

Samami, R., Seidavi, A., Eila, N., Moarefi, M., Ziaja, D. J., Lis, J. A., and Cappai, M. G. (2019) 'Production performance and economic traits of silkworms (Bombyx mori L., 1758) fed with 
mulberry tree leaves (Morus alba, var. Ichinose) significantly differ according to hybrid lines' Livestock Science, 226, 133-137.

Sathis , J., and K. Sujatha (2020) 'Antibacterial activity and efficient use of acetone leaf extract of A. Muricata for improvement of commercial traits in silkworm, B. mori, L.' International Journal of Entomology Research. 5( 4): 130-135.

Sengupta, N., B.D. Singh. and J.C. Muatafi (1972) 'Nutrition of silkworm B. mori L. I- Studies on the enrichment of mulberry leaf with various sugars, proteins, amino acids and vitamins for vigorous growth of the worm and increased cocoon crop protection' Indian J. Sericulture, 11-27.

Singh, V.K. and A. Saxena (2015) 'Studies on the effect of the chloroform extract of Ocimum basilicum (family: Lamiaceae) on the III and V instar larvae of silkmoth Bombyx mori L. (family: Bombycidae)' Online Int. Interdisciplinary Res. J., Vol. V (V): 53-60.

Sridevi, G., R.N. Basker. and M.C. Devaiah (2003) 'Influence of medicinal plant extract on cocoon parameters of silkworm, Bombyx mori L. (Abstr.).' National conference on tropical Sericulture for Global competitiveness. CSRTI. Mysore.

Zannoon, A.A. and S.M. Omera (1994) 'Efficiency of certain natural materials as mountages for mulberry silkworm, Bombyx mori L.' Egypt. J. Appl. Sci., 9 (8): 691-696 